\title{
Military Integration of Armed Groups as a Conflict Resolution Approach in Africa: Good Strategy or Bad Compromise?
}

\author{
Cosmas Ekwom Kamais \\ Department of International Relations, Conflict and Strategic Studies, Kenyatta University, Kahawa, Kenya \\ Email: Kamaiscosmas@yahoo.co.uk
}

How to cite this paper: Kamais, C.E. (2019) Military Integration of Armed Groups as a Conflict Resolution Approach in Africa: Good Strategy or Bad Compromise? Open Access Library Journal, 6: e5518. https://doi.org/10.4236/oalib.1105518

Received: June 3, 2019

Accepted: June 25, 2019

Published: June 28, 2019

Copyright $\odot 2019$ by author(s) and Open Access Library Inc.

This work is licensed under the Creative Commons Attribution International License (CC BY 4.0).

http://creativecommons.org/licenses/by/4.0/

\section{(c) (1) Open Access}

\begin{abstract}
This paper examines the integration of armed groups into security sector of a country, especially the military, as an approach to peace building. It takes an overview of such approaches in South Sudan, Democratic Republic of Congo (DRC) and the Central African Republic (CAR). The paper argues that while such an approach is good for peace's sake, it usually fails to attain peace in the long term due to its rushed conceptualization and implementation, lack of sufficient resource support, lack of political will, vested interests by the armed groups and external actor, among other reasons. Furthermore, the paper notes that integration leads to disaffection among the rank and file of the national military; since some of the rebel elements become their seniors without proper qualifications. The battle animosities and suspicion tend to persist even after the integration. All these are factors that are likely to lead to breakdown of a peace agreement; and eventual resumption of conflict with formation of splinter factions of the integrated rebels, as is the case with National Congress for the Defence of the People (CNDP) elements in DRC who mutinied and formed M23 movement. In advancing the argument of failures in military integration as a conflict resolution strategy, the paper glances back at the Montevideo convention on the roles and obligations of states. It points out an interesting line of thought that states engage with states and not non-states. Thus, engaging with armed groups runs the risks of recognition and legitimization of armed groups and may lead to more demands. Such engagements also risk sending the wrong message that "violence pays" and this can lead to formation of more armed groups to agitate for their interests. However, the paper recognizes that if post conflict integration of armed groups into security structures of a country is done properly and with sufficient support, it is likely to lead to long term peace as is the case in post-genocide Rwanda. This is especially in times of conflict where alleviation
\end{abstract}


of human suffering is primary. The paper concludes with the call to re-evaluate the approaches of integration of armed groups into the security structure in a wholistic manner as part of the security sector reforms (SSR). And since every country's situation is different in terms of conflict history and culture, a fit-all template is not feasible and thus integration approaches need to take these diversities into consideration.

\section{Subject Areas}

International Relations, Military Science

\section{Keywords}

Military Integration, Armed Groups, Conflict Resolution, Compromise, Strategy, Peacebuilding

\section{Introduction}

Conflicts have increasingly changed from conventional military confrontations to low intensity conflicts employing mostly asymmetric tactics [1]. The tactics that were employed in independence and emancipation struggle in countries that were faced with colonialism or oppression of one kind or another [2]. While these are meant to overcome powerful conventional forces, it has become a tactic of choice for militia groups that are in pursuit of varied agenda. Over time, and in the argumentation of this paper, warlords have engaged in militia activities through forming armed groups to pursue personal interests. These interests include, but not limited to, access to power in the legitimate governance of a state and access to mineral resources [3].

In resolving these problems, states and international bodies have favored appeasement approaches that take the form of military integration of armed groups into the security structure of the state. As a conflict resolution strategy, military integration of armed groups is a concept that has attracted diverse definition from scholars. According to Licklider [4], military integration is when "individuals are brought into the new military in positions similar to the ones they occupied in the prior organization". This, in essence, is cross-transferring without regard to qualifications or other relevant criteria. Glassmyer and Sambanis [3], refer to the process as "rebel-military integration" and according to them it occurs when rebels are integrated into a "new national army". However, Melin [5] notes a new army does not imply the disbandment the former and creation of a completely new army. Basically, such approaches employ a variation of carrot and stick method; but weigh more towards the carrot. Unlike the Pacific conflict management approaches, prescribed chapter VI of the UN charter, that seek to attain win-win outcomes, most of the appeasement approaches do put the states governments in a weaker bargaining position through too much comprise. For instance, rebel groups are usually offered blanket am- 
nesty despite the heinous atrocities they have committed [6]. They are then offered positions of leadership in government and security apparatus (military), control of certain territories, among other incentives.

While these can have the positive effect of enticing other armed groups to lay down arms, it equally has the potential of inviting more demands from the particular armed group(s) at the negotiating table who would want the government to cede more ground [7]. It also encourages others to form or join armed groups in the hope that they will eventually be invited to the negotiating table where they will be able to obtain their real desires for power and resources. Furthermore, the favouritisms extended to the irregular forces in the form of higher ranks and positions without duly earning them lead to a feeling of disaffection from the regular forces who have worked hard to earn their ranks and have fought the armed group(s) that are now placed to boss over them [8].

Whereas such an approach is good for the sake of peace, it should, in the argument of this paper, be measured, reasonable and applied without playing into the demands of armed groups; that are purely in pursuit of personal interests dressed as popular cause. Scholars have noted that there are state officials, or state agencies, who are directly or indirectly involved in the activities of non-state armed actors; sometimes for ideological reasons e.g. secret support for rebels, sometimes because of personal interests such as political career, corruption, family or clan ties, clientelism, and profit [9]. Specifically, the approach where the armed group(s) are invited to join the rank and file of the state military, gain control of government departments and ministries, among others, usually leads to domino effect where more demands are pressed, more people form or join militias, individuals not satisfied with deals offered forming splinter factions to press for their interests, coup de etat, among other undesired outcomes [3].

While all possible approaches should be explored in pursuit of peace, the idea of too more compromise eventually militates against the desired outcome and embroils a state in more conflict. In advancing this argument, this paper is structured such that, it examines the dilemma of engaging armed groups and non-state actors in negations; in the context of international treaties and conventions setting out the duties and obligations of states. The paper notes that whereas there is an implied non-engagement clause between states and non-states entities, a state is obliged to take all necessary measures to ensure pacific settlement of disputes. The paper then reviews peace agreements in South Sudan, Democratic Republic of Congo (DRC), and Central African Republic (CAR); with specific interest on the general reasons why the integrationist peace deals failed. Thereafter, the paper queries if the military integration approach is a good strategy or a bad compromise as a conflict resolution strategy. The paper then attempts to suggest a way forward in the face of challenges encountered while using military integration of armed groups as a conflict resolution and peacebuilding strategy. In concluding, the paper emphasizes the need to take a 
wholistic review of military integration approach to conflict resolution and peacebuilding especially in the face of diverse socio-cultural and political contexts of conflicts in each state.

\section{Dilemma in Engaging Non-State Entities for Peace Agreements}

Article 10 of the Montevideo convention of 1933 requires that states use the recognized pacific means of settling disputes in pursuit of their primary interest of preserving peace. These pacific means are spelt out in Article 33, Chapter VI of the UN Charter and include; negotiation, enquiry, mediation, conciliation, arbitration, judicial settlement, resort to regional agencies or arrangements, or other peaceful means of their own choice [10]. Conflicts existence of levels of interaction in any conflict. It usually entails more than one party as in inter-state conflicts, intra-state conflicts, inter-ethnic conflicts and inter-personal. It also entails conflictual paradigms within a person as in the case of intra-personal conflicts. Scholars have noted that Conflict is much more than what meets the naked eye as i.e. direct violence [11]. Galtung [11] further notes that, "there is the violence frozen into structures, and the culture that legitimizes violence and thus to transform a conflict between some parties, more than a new architecture for their relationship is needed i.e. the parties have to be transformed so that the conflict is not reproduced forever". While this paper does not intend to pursue this line of thought, it highlights the breadths and depths of conflict resolution and transformation process that requires a shift in thinking and approach from old and rigid methods to more flexible and pragmatic ones.

Peace processes tend to threaten armed groups position, status, room for maneuver and opportunities to pursue their political and/or economic objectives [12]. In a typical peace process disarmament, and eventually, disbandment of armed group is done. Other armed groups would probably be forced to transform themselves and become political forces or integrate into official state structures, while criminals, mercenaries, or marauders would simply risk economic profits and face measures under law enforcement [9]. Thus, these efforts pose an existential threat to these actors, and consequently they are more likely to challenge than to support any steps that would strengthen or reestablish the state's monopoly on the use of force. As Stedman [13] notes, these saboteur moves by armed groups have been a feature in most international intervention, in many conflicts such as Bosnia and Kosovo to Somalia, Haiti, Afghanistan, and the Democratic Republic of the Congo.

Peace building efforts are often conducted against the backdrop of vested interests by armed groups on the one hand, and the need to create a secure environment through accommodation of at least the most powerful of the non-state armed actors through inclusion in a political process that grants them some kind of political influence, on the other hand [9]. Engaging non-state armed actors poses a dilemma of more demands and legitimization of the armed groups; 
which may embolden them or inspire other groups. This is a real problem especially the use of established para-state structures by warlords, rebels, big men, or militias, as temporary solutions and building blocks for reconstructing statehood [14]. Another problem is whether such an approach would simply risk the strengthening and legitimization of armed groups thus challenging state's monopoly on the use of force. Additionally, such an approach runs the risk of sending the wrong message, that "violence pays", especially when too much attention is devoted and privileges are granted to non-state armed actors who have already benefited from war and shadow economies [9]. Such pitfalls may not only trigger increasing demands by such actors but also seriously damage the credibility and legitimacy of external actors in the court of public opinion [15]. Nonetheless, and in the face of all these moral hazards, peace has to be pursued by all means. A brief review of some peace process in Africa, that attempted to employ integration, will be done in the proceeding sub-sections. They include in countries like South Sudan, Democratic Republic of Congo (DRC) and Central African Republic (CAR).

\subsection{South Sudan Peace Agreements}

The Republic of South Sudan attained her independence by becoming the $53^{\text {rd }}$ country in Africa in 2011. This is after a long struggle for independence against Sudan. The 2005 Comprehensive Peace Agreement (CPA) set the stage for South Sudan's independence. However, it left a few critical issues unaddressed such as the status of the Abiyei region, in South Kordofan, as to whether is in the north or south. The Sudanese civil war, which erupted in 1983 after that failure if the Addis Ababa agreement, pitied the Khartoum administration against the Sudanese Peoples Liberation Movement (SPLA), a rebel movement formed and by the late Colonel John Garang de Mabior. The aim of the SPLA was to fight for the secession and independence of the predominantly black and Christian south from the predominantly Muslim north.

The conflict occasioned huge loses in lives and property with more than two million people dead, four million uprooted and some 600,000 people sought shelter beyond Sudan's borders as refugees [16]. After several failed attempts to end the war by international organizations and states, in 1993 IGAD stepped and embarked on a long process that would culminate into the signing of the CPA in 2005. This gave way to eventual independence of South Sudan after a referendum as part of the requirements of the 2002 Machakos agreement on a broad framework, setting forth the principles of governance, the transitional process and the structures of government as well as on the right to self-determination for the people of South Sudan, and on state and religion. A resounding majority (98.83\%) of the South Sudanese voted for independence during the referendum held between 9-15 January 2011 [17].

With the establishment of the new state of South Sudan came numerous challenges that were earlier considered as teething problems. However, a critical 
examination of the conflict issues points to deep seated ethno-cultural differences that tend to flare up to violence. Control of resources and power by the dominant ethnic groups of Dinka and Nuer has occasioned deadly confrontations such as those seen in 2013; leading to the fallout between President Salva Kiir and his Deputy President, Dr. Riek Machar [18].

In the 2013 agreement a key part of the deal was the holding of general elections and the subsequent integration of rebel forces into a unified government. The peace agreement was, among others, meant to restore peace and stability after a bloody conflict that broke out in late 2013, two years after South Sudan obtained independence from the Republic of Sudan. However, the implementation of peace agreement became untenable due to deep seated differences and animosity among the rival parties, lack of trust and political will on the side of the government, lack of ownership of the peace deal which was perceived as imposed on parties involved and the lack of funds to facilitate the implementation of certain provisions of the deal; including the formation of electoral body, holding of general elections and the merger of the armed groups into regular forces.

After the failures and eventual collapse of the 2015 peace agreement, the opposing sides signed and the Revitalized Agreement on the Resolution of the Conflict in the Republic of South Sudan (R-ARCSS) in September 2018 in Khartoum. This was a product of a deal brokered by the Inter-Governmental Authority on Development (IGAD). It has been hailed as a breakthrough for reversing the brutal civil conflict that has cost an estimated 400,000 lives and displaced more than 4 million people since its onset in December 2013 [19]. The critical provisions of the R-ARCSS include, reaffirmation of the Cessation of Hostilities Agreement (CoHA) signed in December 2017, separation and reporting of forces, formation of joint military coordination boards, cantonment of forces, restructuring and reformation of the SPLA (now South Sudan People's Defense Forces, SSPDF) involving the incorporation of various military factions and disarmament, demobilization, and reintegration (DDR) and security sector reform (SSR) [20].

Despite 55\% of South Sudanese being optimistic that the peace agreement will see the government and the opposition work together for peace [21], there have been noted failures in implementation of the R-ARCSS. On military and security developments, it has been noted that cease fire has not been implemented with government forces continuing crackdown in areas that are perceived to be anti-government in Upper Nile, Jonglei, and Central Equatoria [20]. Non-signatory rebel factions, such National Salvation Army (NAS) led by Thomas Cirrilo in Central and Western Equatoria have faced offensive onslaught by government security forces. IGAD member states, especially Uganda and Sudan, have appeared to give tacit support to the government offensive for their own geopolitical interests. Cantonment of forces is also facing challenges with the SPLM-IO complying with the provisions of R-ARCSS while the government has 
remained virtually unresponsive towards cantonment. While Machar's forces stand to gain in terms of political points for compliance, opportunity for recruitment and training, logistical support, among others, Kiir's forces on the other hand stand to lose through revealing their strength, arduous task of providing pay and sustenance for 200,000 - 300,000 troops, opposition seeking parity of forces and thus strong opposition among other reasons [20].

Merger of the security forces is another important provision of the R-ARCSS. Sudan and Uganda are likely to take an active role in the process. However, a full merger of government and opposition forces would undermine Dinka control of the security sector by the (re)inclusion of large numbers of Nuer, Shilluk, and Equatorians, meaning there is limited government incentive to pursue full integration [20]. Thus, parties are likely to publicly promote the idea of a complete merger while presenting the lack of progress as the result of insufficient resources to pressure donors and to forestall criticism. The eventual outcome will be a partial merger or non-merger. This will ensure that the Dinka control is retained and this is likely lead to collapse of the R-ARCSS as the SPLM-IO will feel that they have been taken for a ride.

The 2018 R-ARCSS is the latest attempt to find peace in South Sudan; though, as its predecessor agreements, it is facing challenges that threaten to derail and even collapse it. Among others, the prospect of receiving formal ranks and pay was used as an inducement to induce buy into the agreement and reduce reservations [20]. However, these incentives had only temporary success in the past when payments have been sporadic and benefits failed to materialize and finally undermined prior integration efforts in Western Equatorial and Jonglei. Lack of political will, geopolitical interests by external actors, resenting rebel factions and lack of financial resources are real threats to the R-ARCSS.

\subsection{Elusive Peace in the DRC}

Since the 1990s the DRC has been mired with conflicts especially in the Eastern part of DRC bordering Uganda, Rwanda and Burundi with the Council for Foreign Relations [22] estimating that up to six million lives have been claimed, either as a direct result of combat or due to conflict-related disease and malnutrition. Scholars have come to characterize the conflict in the DRC as intractable conflict [23]. Intractable conflicts are those conflicts that lie at the frontier of the field i.e. the conflicts that stubbornly seem to elude resolution, even when the best available techniques are applied [24]. The conflict in Eastern DRC has seemed to elude all attempts to attain a resolution. This evidence by the numerous attempts to implement various peace agreements that have been put forward. Ahere [23] notes that despite the establishment of a democratically elected government in 2006, the government has struggled to consolidate peace in the vast DRC territory. Eastern DRC has consistently experienced high insecurity and repeated incidences of violence and this has led interference of neighboring countries. Whilst significant attention has been paid to the DRC by both re- 
gional and international actors, the humanitarian crisis and violence still continue [23]. In spite of the numerous peace talks, elaborate peace processes and signed peace agreements, the DRC continues to experience high levels of human insecurity.

The DRC has experienced conflicts since the 1990s with the first Congolese war (1996-1977) ending with the ouster of President Mobutu Sseseko by Laurent Kabila with the support of Angola, Uganda and Rwanda [23]. A fallout between Kabila with Uganda and Rwanda led to the second Congolese war which began in 1998 with the DRC being supported by Angola, Chad, Namibia, Sudan, Zimbabwe and the Maï-Maï and Hutu-aligned forces against Burundi, Uganda, Rwanda and the Movement for the Liberation of the Congo, the Congolese Rally for Democracy (RCD) and Tutsi-aligned forces. This war ended with a series of four incremental peace agreements; the Lusaka Ceasefire Agreement (1999), the Sun City Agreement (April 2002), the Pretoria Agreement (July 2002) and the Luanda Agreement (September 2002) that ultimately contributed to the Global and Inclusive Agreement of December 2002 which finally ended the war [25] [26]. However, the raft of peace agreements did not result in stemming conflicts in the DRC [27]. This is due to the fact that the conflict had many actors whose interests were not sufficiently addressed to compel them to agree to enter into any agreement(s) or respect the one(s) entered into [28].

The current conflict in the DRC goes back to 2003, when the country was being unified after years of civil war, and all belligerents were obliged to integrate their troops into the Armed Forces of the Democratic Republic of the Congo (FARDC) [23]. However, a group of officers from the Rwanda-backed RCD, refused to join the FARDC as per the peace agreement deal. Instead, they formed a rebel movement which they called the National Congress for the Defence of the People (CNDP). In January 2009, the CNDP was eventually integrated into the FARDC after a peace deal. Unfortunately, as a pre-emptive move to prevent their leaders from being dispersed from Eastern DRC to other parts of the country, CNDP members in the FARDC mutinied on April, 2012 and subsequently formed the March 23 (M23) rebel group [29].

Besides the varied interests of Armed groups and external actors in the DRC, various national and multinational corporations (MNCs) have allegedly been fuelling and supporting the conflict in DRC. The MNCs seek to obtain mining concessions or contracts in the country on terms that were more favorable than they would have received in countries where there was peace and stability. It is posited that the MNCs have developed networks of key political, military and business elites to exploit the DRC's natural resources [30]. The MNCs have also been accused of trading with rebels who take control of mineral-rich areas, set up financial and administrative bodies with the aim of obtaining revenue from the minerals. The revenue so gained from trade in the DRC's natural resources has assisted all the armed groups to fund their participation in the conflict and to enrich themselves [31]. 


\subsection{Searching for Peace in the CAR}

The conflict in the Central African Republic is a protracted social conflict pitying the government against militia groups comprising the predominantly Muslim Seleka armed group and the Christian anti-balaka armed group. Previously, the government of President François Bozizé fought the Central African Republic Bush war from 2004 until a peace agreement was reached in 2007 [32]. The Bush war was a conflict between the Union of Democratic Forces for Unity (UDFR) and the government forces leading to the displacement of approximately 10,000 people [33]. Other armed groups in the conflict included the People's Army for the Restoration of Democracy (CAR) (APRD), Grouped actionpatriotique pour la liberation de Centrafrique (GAPLC), the Movement of Central African Liberators for Justice (MLCJ), the Front démocratique Centrafricain (FDC), and Union of Republican Forces (UFR).

In an attempt to find a lasting peace, several peace agreements were brokered and signed between 2007 and 2012 [34]. The Global Peace Accord signed in Libreville, Gabon on 21 June 2008 was the most important. It was first signed by the ARPD, UFDR, and FDPC groups. The agreement granted amnesty for any acts perpetrated against the state prior to the agreement, and called for a disarmament and demobilization process to integrate former rebels into society and the regular CAR armed forces. Of all the rebel groups, FDPC has a major threat to the government. The FDPC's AbdoulayeMiskine signed a peace agreement with the government on 2 February 2007 in Syrte, Libya [34]. The deal called for a cessation of hostilities, the billeting of FDPC fighters and their integration with Forces ArméesCentrAfricaines (FACA), the liberation of political prisoners, and the integration of FDPC into government. Subsequently, in August 2007, Miskine was appointed as a presidential adviser but he rejected the appointment on the basis that the government had violated the Syrte agreement [35]. He was primarily concerned that the government would fail to protect him from prosecution by the International Criminal Court (ICC). ICC had initiated investigations into war crimes alleged to have occurred during Bozize's 2002-2003 coup attempt. against the Patasse government, andMiskinewas a top suspect. Other rebel groups signed on to the agreement later, or signed similar agreements with the government. After the bombing of the UFDR headquarters in Birao, the Birao Peace Agreement was signed on 1 April 2007 UFDR and the CAR government [36]. This provided for amnesty for the UFDR, its recognition as a political party, and the integration of its fighters into the national army. The remaining rebel groups continued fighting the government but later signed various peace agreements after comprise on their various demands were met.

On 10 December 2012, the conflict restarted with Sélékarebel group accusing President Bozizé of violating the terms of their earlier agreement, subsequently overthrowing him on 24 March 2013, and rebel leader Michel Djotodia declared himself President of the Central African Republic [37]. Inclusion of approximately 16 ex-seleka rebel members in the new government displeased the 
members of the opposition who boycotted the government. The subsequent non-recognition of Djotodia as the President, and the lack of support for his transitional plans, by African leaders further compromised the new president's position [38]. Despite Djotodia's resignation in 2014, the conflict in CAR continued [39]. FaustinTouadéra was later appointed in 2016 as the CAR President with support from the UN Secretary General and the international community especially France and Russia [35].

\section{A Good Strategy or a Bad Compromise?}

The above overview of various attempts to broker peace indicates a common approach that underlies the peace agreements. Those who broker the peace deals tend to accommodate the rebel groups into the government structures; both politically and in the security sector especially in the military [40]. It is estimated that almost a third of the peace building strategies in the 1990s employed military integration approach; 23 out of 27 occurring in Sub Saharan Africa [3]. While this is a sacrificial token for peace in the short term, in the long run it becomes a problem. In observing the effectiveness of integrations as a peace building strategy Glassmyre and Simbanis [3] note that part of the reason the approach has failed is because it does not provide credible security guarantees but rather it serves mostly as an economic strategy of providing employment to rebels. However, to be effective, military integration could be combined with political power-sharing, although the evidence on this option has been noted to be only suggestive [3].

An analysis of rebel-military integration has showed they have not been an effective peace building mechanism, mostly due to poor implementation of the agreements [3]. It has been observed that most militia groups form and coalesce along ethnic lines and this poses a great challenge during post conflict integration in the form of hybrid security groups or auxiliary military groups [41]. The signs of quick compromise serve as an incentive for armed groups to push for terms that mostly favor them, at individual level, with little regard for the course they purported to be fighting for. This points towards the use of violence to vent grievances in order to pursue individual or ethnic greed rather than the needs [42]. Such arrangements encourage other individuals with interest in the states politics to resort to armed tactics to push for their agenda. This is with the encouragement that they will eventually be called to the negotiating table and their demands of inclusion in the political and military structures will likely succeed. It is noted that the integration process in South Sudan between 2006-2013 was poorly-conceived and implemented, with limited support from third party actors [43]. The open-door nature of South Sudan's integration process created incentives for armed rebellion, and the failed military integration process threatened stability. At the end the integration became an end in and of itself rather than a transitional measure to contain former combatants while the government worked out a more long-term solution for South Sudan's security sector. 
The issues of ranking system, more so in the military, is a big concern. Often, the deals brokered with armed groups includes direct transition and integration of former rebels into the rank and file with their rebel ranks. It becomes absurd for a former low-ranking officer, who might have defected to a rebel movement and gaining the rank of a General for instance, come back and be in charge of his former superiors. It should be noted that ranks in a professional military organization are earned in structured way as provided for in the terms and conditions of service. The officers are required to earn their ranks through requisite courses, examinations, years of service, and competence. With a rebel who just ascended without any of the criteria to come and boss over professional officers, definitely results in disaffection. This might erupt into rebel factions in future since the integrated militias neither feel completely at home, nor the are they whole welcomed by the professional officers; who feel that the rebels have been handed what is their rights. The lack of proper competence assessment of the rebels, so as to grade them for reasonable entry levels, further complicated the problem. As Glassmyre and Sambanis [3] noted military integrations as a peace strategy was done with no clear plan and rebels were simply invited to join or the government restructured the military to include previously excluded minority groups. In the DRC, the integration process required immediate integration process of different ethnic groups that made up the security forces. The process was not successful partly because the Rank alignment of the new military was based on seniority within militia groups [8]. There was also lack of retraining of the militia to boost their professional capacities. Ethnic loyalty and alignment of the militias made it problematic when it comes to deployment. It is noted that FARDC soldiers and officers refused to be deployed to areas where their ethnic groups were not in charge. This for instance led to the 2013 rebellion of the CNRD faction forming the M23 movement [29]. Civil war rivalries also continued and had been a source of tension even among the senior officers.

However, it is not all 'doom and gloom' in this approach of integration as a peace building strategy. The integration approach entails three models that have been employed by various countries in an attempt to stabilize and attain peace. These include the consent model which entails a comprehensive negotiated settlement involving all parties and mediated by a third party, demobilization model involving the post conflict downsizing of the military without involving the militia as applied in Ethiopia in 1991 after the defeat of Mengistu Haile Mariam [44], and finally the coercive model which involves military operations to forcefully demobilize armed groups as attempted in Somalia in 1993 [45]. In a assessing the post-genocide Rwandan example, it is noted that the consent model worked successful and saw the formation of government of national unity with integration of the warring parties into the security structures of the army [46]. The model of Rwandan integration was continuous process effected through the traditional Ingando (solidarity group) concept where individuals were required to subjugate their interests to the national interest. This implies a 
concept of patriotism that puts the interest of others and the nation before self. However, in most African cases, patriotism is non-existent and instead ethnic loyalties are the prime pursuits as is the case in the Somalia conflict [41] [47].

\section{Possible Way Forward Way Forward}

Integration as a peace building approach is becoming more popular in conflict resolution strategies. This due to the fact that it hopes to achieve a win-win outcome for the main parties to a conflict. It is original intent is to pursue acceptable compromise for the sake of peace. However, as noted in the preceding cases, the process has not often worked due to the influence of individual and ethnic interests [47]. The poor plan and rushed implementation of the process is also a main reason why integration has tended to fail [43].

As noted, the post-genocide Rwandan experience has been successful due to the comprehensive and continuous approach to the process and subjugation personal/ethnic interest to that of the state [46]. This speaks to the need of having; a well thought out integration process with popular support as part of the wider Security Sector Reform (SSR) approach, support from external partners, a continuous process rather than a rushed process, capacity development of the integrated militia among others. At the heart of the process should be the call to patriotism and advocacy for the common good rather than pursuit of personal/ethnic gains. As Warner [43] notes, for the integrations process to be successful, it should be pursued as an outcome of the SSR process rather than an end in itself.

This leaves the question on how to make integration work as a peace building strategy. The first step is the designing of integration. Peace scholars have often noted that, the structure of military integration is believed to hold the key to the successful implementation of the process, as some integration agreements fail because they are poorly structured and not fully implemented [3]. In developing integrations strategies, the particular circumstances of the state should be taken into account. While lessons can be drawn from other integration experiences, it is best to adapt strategies to a particular environment since a fit-all template does not exist [8]. Attention should be given to the failure factors and the need to avoid them.

Integration is part of a wider SSR/DDR process and thus it is capital intensive to implement. This often goes beyond the capacity of the post-conflict state; and requires external financial support. It is noted that the failures in Burundi's integration process were due lack of funds to effect it; whereas successes attained in Bosnia and Cambodia was due to the massive support amounting to about US \$250 million train and equip programme by USA, Saudi Arabia, Kuwait, United Arab Emirate, Malaysia and Brunei [8]. It is in the best interest of regional organizations to take the lead in this aspect since continued instability will affect them. The wider international community can extend further support to augment regional organization efforts 
While some peace experts note that an integration process is likely to be successful when implemented within five years after the conflict [6], others argue that it requires more time. As Rusagara [46] contends, part of the reason that the post-genocide Rwandan integration, was successful is due to its continuous nature. Rwanda adopted the Ingando concept that is a participatory model with call to patriotism and love of neighbor at its core. The failure of integration process in the DRC has been partly due to the poor conception of the process and hurried implementation [8]. Retraining of militias into a professional outfit definitely takes time. The cultivation of trust between the national army and the rebels forming the integrated army is not a short-term undertaking considering that these were war rivals that were after each other's heads. It is therefore prudent to embark on the integration process immediately but have its implementation drawn out with milestones to guide execution. Periodic and objective review of the process is a crucial part leading to an eventual termination when the set objectives have been attained.

\section{Conclusions}

This paper sought to examine the concept of military integration of armed groups/rebels into the security structure of a state as an approach to conflict resolution and peace building. Due to the failures of templated methods of approaching military integration, the paper emphases the need of more situation tailored approaches due to unique conflict situations. Pursuit for peace in a conflict situation is a primary humanitarian concern of a state, the international community and humanitarian agencies. Many Pacific and coercive approaches tend to be employed with mixed outcomes. The integration of armed groups into a post conflict peace settlement has been employed in many conflict situations. Unfortunately, most of them have tended to fail and lead to relapse into conflicts. Parties to a conflict tend to pursue collection of personal interests which they aim to bulldoze through war or peace agreements. While compromising for the sake of peace is a good idea, it risks emboldening the concerned armed group, or others, to press for more demands. Acquiescing to the demands further risks sending the wrong impression that violence pays, and this may encourage formation of more armed groups to form and push for their demands.

The implementation of such integration approaches is usually faced with obstacles. The poor conception and hurried implementation, coupled with lack of financial resources and political goodwill, often reverse the expectations. The problem of integrating rebels to out rank and boss over national army soldiers who feel they earned their ranks, is a challenge that requires a careful approach. Trust issues between integrated rebels and national army soldiers also do persist. However, planning and implementation of post conflict rebel-military integration have the potential for success if done carefully; taking into consideration the socio-cultural and political diversities. Therefore, and in the face of all the dilemmas and challenges, there is need to re-evaluate the integration of armed 
groups into standing armies as a peace building approach.

This paper adds to existing body of research on the subject by requiring a case-by-case implementation of military integration strategies. Since this paper does not encompass statistical analysis of military integrations approaches, successes and failures, further quantitative research into this area is needed in order to inform policy.

\section{Conflicts of Interest}

The author declares no conflicts of interest regarding the publication of this paper.

\section{References}

[1] Kamais, C.E. and Kaboyo, L.N. (2019) Preparedness of Security Managers to Counter Dirty Weapon Threat. American Journal of Humanities and Social Science Research, 3, 97-102.

[2] Mahan, S. and Griset, P.L. (2013) Terrorism in Perspective. Third Edition, Sage Publications, Inc., Thousand Oaks.

[3] Glassmyre, K. and Simbanis, N. (2008) Rebel-Military Integration and Civil War Termination. Journal of Peace Research, 45, 365-384. https://doi.org/10.1177/0022343308088816

[4] Licklider, R. (2014) So What? In: Licklider, R., New Armies from Old-Merging Competing Military Forces after Civil Wars, Georgetown University Press, Washington DC, 3.

[5] Melin, A. (2016) Military Integration of Former Enemies: Do Previous Identities Matter for the Creation of a New "We"? Uppsala University, Department of Peace and Conflict Research. Uppsala University, Uppsala.

[6] Hoddie, M. and Hartzell, C. (2003) Civil War Settlements and the Implementation of Military Power-Sharing Arrangements. Journal of Peace Research, 40, 303-320. https://doi.org/10.1177/0022343303040003004

[7] Wehrey, F. and Ahram, A.I. (2015) Taming the Militias: Building National Guards in Fractured Arab States. Carnegie Endowment for International Peace, Washington DC.

[8] Knight, M. (2009) Security Sector Reform Post-Conflict Intergration. University of Birmingham. Global Facittation Network for Security Sector Reform, Birmingham.

[9] Hofmann, C. and Schneckener, U. (2011) Engaging Non-State Actors in Tate and Peace Building: Strategies and Options. International Review of the Red Cross, 93, 1-19. https://doi.org/10.1017/S1816383112000148

[10] United Nations (1948) Chapter VI: Pacific Settlement of Disputes. https://www.un.org/en/sections/un-charter/chapter-vi/index.html

[11] Galtung, J. (1996) Peace by Peaceful Means: Peace and Conflict, Development and Civilization. Sage Publications, London.

[12] Jarstad, A.K. (2008) Power-Sharing: Former Enemies in Joint Government. In: Jarstad, A.K. and Sisk, T., Eds., From War to Democracy: Dilemmas of Peace-Building, Cambridge University Press, Cambridge, 105-133.

https://doi.org/10.1017/CBO9780511755859.005

[13] Stedman, S. (1997) Spoiler Problems in Peace Processes. International Security, 22, 
5-53. https://doi.org/10.1162/isec.22.2.5

[14] McCartney, C. (2005) Engaging Armed Groups in Peace Processes: Reflections for Practice and Policy from Colombia and the Philippines, Conciliation Resources. In: Ricigliano, R., Ed., Choosing to Engage Armed Groups and Peace Processes, Vol. 16, Accord, London, 9.

[15] Kuperman, A. (2008) The Moral Hazard of Humanitarian Intervention: Lessons from the Balkans. International Studies Quarterly, 52, 49-80. https://doi.org/10.1111/j.1468-2478.2007.00491.x

[16] United Nations Mission in Sudan (2011) Comprehensive Peace Agreement. https://unmis.unmissions.org

[17] Tehran Times (2011) First Day of South Sudan Referendum Ends Peacefully. https://www.tehrantimes.com/news

[18] Custing, J. and Harding, T. (2013) Oil in South Sudan: Implications or International Experience. University of Oxford, Oxford.

[19] UNHCR (2018) Summary Conclusions on the Dissemination of the Revitalized Agreement on the Resolution of the Conflict in the Republic of South Sudan (R-ARCSS) for Refugees. https://data2.unhcr.org

[20] Ryan, K. (2019) Taking Stock of the Revitalized Agreement on the Resolution of the Conflict in South Sudan. https://africacenter.org

[21] South Sudan Civils Society Forum (2018) Revitalizing Peace in South Sudan: Citizens Perception of the Peace Process. http://www.centrepeacejustice.org

[22] Council for Foreign Relations (2002) Democratic Republic of Congo: The Sun City Agreement.

https://www.cfr.org/interactive/womens-participation-in-peace-processes/democrat ic-republic-congo

[23] Ahere, J. (2012) The Peace Process in the DRC: A Transformation Quagmire. https://www.accord.org.za/publication/peace-process-drc

[24] Burgess, H. and Burgess, G.M. (2003) What Are Intractable Conflicts? https://www.beyondintractability.org

[25] U.S. Department of State (2005) Peace Agreements: Democratic Republic of the Congo. United State Institute for Peace (USIP), Luzaka.

https://www.usip.org/publications/2005/03/peace-agreements-democratic-republiccongo

[26] U.S. Department of State (2002) Peace Agreements: Democratic Republic of the Congo (DRC)-Rwanda. United State Institute of Peace, Pretoria.

https://www.usip.org/publications/2002/09/peace-agreements-democratic-republiccongo-drc-rwanda

[27] Nantulya, P. (2018) When Peace Agreements Fail: Lessons from Lesotho, Burundi, and DRC.

https://africacenter.org/spotlight/when-peace-agreements-fail-lessons-from-lesotho -burundi-and-drc

[28] Stearns, J. (2011) Dancing in the Glory of Monsters: The Collapse of the Congo and the Great War of Africa. Public Affairs, New York.

[29] BBC News (2012) Rwanda Supporting DR Congo Mutineers. http://www.bbc.co.uk/news/world-africa-18231128

[30] Shah, A. (2010) The Democratic Republic of Congo. http://www.globalissues.org/article/87/the-democratic-republic-of-congo\#AnIntern ationalBattleOverResources 
[31] Vircoulon, T. (2011) Behind the Problem of Conflict Minerals in DR Congo: Governance.

https://www.crisisgroup.org/africa/central-africa/democratic-republic-congo/behin d-problem-conflict-minerals-dr-congo-governance

[32] Uppsala Conflict Data Program (2013) Uppsala Conflict Data Program Conflict Encyclopedia, Central African Republic, In Depth: The Seleka Rebellion. https://ucdp.uu.se/

[33] The New Humanitarian (2006) Concern as Civilians Flee, Government Denies Capture of third Town.

http://www.thenewhumanitarian.org/report/61544/car-concern-civilians-flee-gover nment-denies-rebel-capture-third-town

[34] USA Today (2007) Central African Republic, Rebels Sign Peace Deal. http://usatoday30.usatoday.com/news/world/2007-04-13-central-africa N.htm

[35] Luhn, A. (2018) France Warns on Russia Arms and Advisers in Central Africa. https://www.telegraph.co.uk/news/2018/10/29/france-warns-russian-arms-adviserscentral-african-republic

[36] Panika, C. (2011) Central African Rebels, Government Sign Truce Pact. AFP, Bangui.

[37] United States Department of State (2013) Country Reports on Human Rights Practices for 2013. Bureau of Democracy, Human Rights and Labor, New York.

[38] Reuters (2013) African Republic Leader Accepts Regional Transition Road Map. https://uk.reuters.com/article/uk-centralafrica-rebels/central-african-republic-leade r-accepts-regional-transition-road-map-idUKBRE9330PU20130404

[39] Nako, M. and Ngoupana, P.-M. (2014) Celebrations in Central African Republic as Leader Resigns.

https://www.reuters.com/article/us-centralafrican-djotodia/celebrations-in-centralafrican-republic-as-leader-resigns-idUSBREA090GT20140110

[40] Burgess, S.F. (2008) Fashioning Integrated Security Forces after Conflict. African Security, 1, 69-91. https://doi.org/10.1080/19362200802479772

[41] Wehrey, F. (2018) Armies, Militias and (Re)-Integration in Fractured States. Italian Institute for International Political Studies, Rome.

https://carnegieendowment.org/2018/10/30/armies-militias-and-re-integration-in-f ractured-states-pub-77604

[42] Collier, P. and Hoeffler, A. (2004) Greed and Grievance in Civil War. Oxford Economic Papers, 56, 563-595. https://doi.org/10.1093/oep/gpf064

[43] Warner, L.A. (2016) The Disintegration of the Military Integration Process in South Sudan. International Journal of Security \& Development, 5, 1-20.

https://doi.org/10.5334/sta.460

[44] Young, J. (2006) Peasant Revolution in Ethiopia. Cambridge University Press, Cambridge.

[45] Knight, W.A. (2008) Disarmament, Demobilization, and Reintegration and Post-Conflict Peace-Building in Africa: An Overview. African Security, 1, 24-52. https://doi.org/10.1080/19362200802285757

[46] Rusagara, F.K. (2017) Military Integration as an Integral Part of Peace-Building: The Rwandan Example.

https://www.open.ac.uk/socialsciences/bisa.../africanagency-seminar2-rusagara.pdf

[47] Osman, A. (2007) Cultural Diversity and the Somali Conflict. https://www.accord.org.za/ajcr-issues/\%EF\%BF\%BCcultural-diversity-and-the-som ali-conflict 